\title{
An Overview of the Constitutional Right to Clean Environment and Sustainable Development
}

\author{
Lufuno Nevondwe \\ Kola O. Odeku \\ Faculty of Management and Law, School of Law, \\ University of Limpopo, South Africa \\ E-mail: lufuno3@gmail.com
}

Doi:10.5901/mjss.2013.v4n13p829

\begin{abstract}
This paper looks at the salient provisions of the South African Constitution that seeks to highlights the importance of everyone's right to clean and sustainable environment. Against this backdrop, the paper argues that for this right to be enjoyed there is need to ensure that the environment is protected. For purposes of a robust overview, the paper relied on the decisions of the courts and these were used to assess whether the rights to clean environment have been violated and consequences thereof
\end{abstract}

Keywords: Environment, Sustainable Development, Jurisprudence from courts, strategic policy and legislative interventions

\section{Introduction}

This paper focuses on section 24 of the Constitution of South Africa which provides "everyone to have access to an environment that is not harmful to their health or well-being; and to have the environment protected, for the benefit of present and future generations, through reasonable legislative and other measures that prevent pollution and ecological degradation, promote conservation and secure ecologically sustainable development and use of natural resources while promoting justifiable economic and social development". To this end, the paper will look at government policies, domestic legislation and international laws that talk directly on why it is important to ensure that the right to clean environment is sustained for the present and future generations.

\section{What are Environment Rights?}

The Constitution of South Africa created a fundamental right to the environment (McDonald, 2004), which effectively means that both the government and private persons which include natural persons, companies, and associations and so on are required to act towards protecting their environments (Nevondwe and Mhlaba, 2012).

There are other provisions in the Constitution which also protect environmental rights unlike in the past where deprived communities were discriminated and denied virtual basic social economic rights including environmental rights (Scott and Macklem, 1992). For example, in unfairly discriminated disadvantaged specific communities especially blacks townships like Sophia Town in Johannesburg where many people had to live and work in unhealthy environments (David and Pape, 2002). The relieving news is that, under the current constitutional democratic dispensation, those who were victims of deprivation to environmental rights can claim restitution in terms of affirmative action and restorative justice according to section 9 of the Constitution. Aggrieved victims can also invoke section 34 of the Constitution to seek remedy from the authorities and compel the Government to listen to the concerns of people before decisions are taken, make fair decisions, , give reasons for its decisions and actions and provide dispute resolution of arguments by independent courts (Razzaqu, 2002).

Section 7 of the Constitution provides hope for future delivery of environmental rights. In the events that this seems impossible to achieve or if the rights cannot be fulfilled immediately, effective steps should be taken to promote actions through which their progressive realisation can be achieved (Davis, 2008).

Apart from the Constitution, there are a number of laws, nationally, provincially and locally, such as nature conservation laws, water laws, air pollution laws and so on which protect the environment.. In 1998, the new National Water Act 36 of 1998, the National Forest Ac 30 of 1998, the Marine Living Resources Act 18 of 1998 and the National 
Environmental Management Act 107 of 1998 were passed.

In order to give greater effects to environmental rights entrenched in the Constitution, the National Environmental Management Act ("NEMA) sets out "environmental principles" (Eastwood, 2007). Acts of both the government and private persons must comply with these principles (Van der Linde, 2006) as will be elucidated hereunder.

The NEMA is intended to integrate environmental management countrywide, by establishing principles to serve as a general framework for environmental matters and providing guidelines for the interpretation, administration and implementation of the NEMA and any other environmental law (Le Roux, 2012).

Each organ of State exercising environmental functions is required to prepare an environmental implementation and management plan and thereafter exercise its functions in accordance with the plan (Van der Linde, 2006). The plan is submitted to the Committee for Environmental Co-ordination, Director General of Environmental Affairs and Tourism and in turn to the Minister of Environmental Affairs and Tourism followed by annual reports (Chipkin and Meny-Gibert, 2013).

Section 24 of the Act imposes a duty on any person who causes, has caused or may cause significant pollution or degradation to take reasonable measures to prevent, minimise and rectify significant pollution and environmental degradation (Kotzé, 2007). However, there is no stipulated threshold of the quantum of pollution that triggers the obligation to remedy or remove the pollution and no legislated standards to which contamination must be measured. What is required is the taking of reasonable measures in terms of section 28 of the Act. The expression reasonable measure is therefore subjective. Unless quantum is attached or suggested, polluters of the environment will continue to hide under the section to perpetrate polluting activities.

The polluter might be found liable under the duty of care (Hunter and Salzman 2007). Non-compliance with the duty of care allows a competent authority to require that specified measures be taken (and if not taken, the competent authority may take those steps itself and recover the costs from various parties) (Waite, 2005). Liability is potentially retrospective and pursuant to National Environmental Laws Amendment Act, 44 of 2008, the aim is to make the duty of care retrospective and therefore applicable to pollution or degradation which occurs at any time (Madalane, 2012).

The creation of a "cradle to grave" obligation for pollution or degradation of the environment is extremely important, together with methods of enforcement (Mazmanian and Kraft, 2008). The Act, in terms of section 28 further creates the possibility of a class action against any entity for potential or actual adverse consequences of a particular activity on the environment.

As part of innovation, the Act established a dedicated environmental enforcement team that will enforce compliance and make perpetrators accountable. Environmental Management Inspectors have extensive powers comparable to police officers and may conduct routine search or other searches and seizure operations (Farmer, 2007).

In terms of section 31 of the ACT, the Minister (at national level) and the MEC (at provincial level) are empowered to identify activities that require environmental authorisation prior to commencement and/or geographical areas in which listed activities may not be carried out without pre-authorisation which may not be granted or exemption without compliance with from environmental impact assessment (EIA) regulations.

During 2006, new EIA regulations were promulgated. These listed the activities that would trigger the need for environmental authorisation from the relevant environmental regulatory authorities, usually the provincial environmental department but in some cases in particular, the national Department of Environmental Affairs and Tourism (Therivel, 2012). The environment is everyone's asset, it must be protected and kept clean irrespective of any criticism against the way and manner various establishments are trying to make this possible (Ackerman and Heinzerling, 2001).

\section{Sustainable Development}

Sustainable development is an idea that is relevant at all times whether now or in the near future (Anand, 2000). Sustainable development refers to development that can continue indefinitely because it does not cause harm to the environment (Goodland, 1995). For example, a sustainable forestry industry would mean not cutting down all the trees at the same time to preserve the trees. It means cutting down some of the trees and also planting new trees to replace those harvested, so that there will always be trees in the years ahead ( Samuelson, 2012).

South Africa has signed and ratified certain important international conventions that aim to protect the environment. One of the most important is the Convention on Biodiversity (Naughton-Treves and Holland, 2005). The main purpose of this Convention is to encourage governments to apply the principles of sustainable development in the running of their countries and the management of natural resources (Dudley, 2008).

There is clearly a need to interpret a number of concepts in environmental law, especially concepts such as sustainable development which may be controversial, vague or uncertain (Bartelmus, 2002). More importantly, it is 
imperative that we understand these concepts in the context in which it is being used and in which we find ourselves. This is important because South Africa has a very specific history, one that has shaped the way in which the Constitution has been framed (Crane and Matten, 2007).

Section 1 of the Constitution sets out the founding values of the Republic and describes South Africa as 'one sovereign democratic State founded on the values of human dignity, the achievement of equality and the advancement of human rights and freedoms. The values endorsed by the Constitution give content to the vision of the Constitution, which is primarily one of transforming an erstwhile unjust society (Albertyn and Goldblatt, 1998). Equality, for example, is central to the process of redress and transformation in South Africa (Henrard. 2002). In this respect the Constitutional Court has noted in the case of King v Dykes 1971 (3) SA 540 (RA) that:

"The South African Constitution is primarily and emphatically an egalitarian Constitution. The supreme laws of comparable constitutional States may underscore other principles and rights. But in the light of our own particular history, and our vision for the future, a Constitution was written with equality at its centre. Equality is our Constitution's focus and its organising principle".

The Constitution therefore sets the stage for how we should understand certain environmental principles or concepts. When the opportunity arises to engage these environmental rights, it should ideally be grabbed with both hands. While the concept of sustainable development is fairly new to South African law (Feris, 2008), as early as 1971 a Southern Rhodesian decision recognised that the principle of inter-generational equity can have the effect of limiting other rights, such as property rights. In King v Dykes 1971 (3) SA 540 (RA) Para 44 545G-H., the court asserted that:

\begin{abstract}
"The idea which prevailed in the past that ownership of land conferred the right on the owner to use his land as he pleased is rapidly giving way in the modern world to the more responsible conception that an owner must not use his land in a way which may prejudice his neighbours or the community in which he lives, and that he holds his land in trust for future generations. Legislation dealing in such matters as town and country planning, the conservation of natural resources, the prevention of pollution and regulations designed to ensure that proper farming practices are followed, all bear eloquent testimonies of the existence of more civilised and enlightened attitude towards the rights conferred by ownership of land".
\end{abstract}

This judgment mirrors the very early sentiments of the Brundtland Report, which described sustainable development as "development which meets the needs of the present generation without compromising the ability of future generations to meet their own needs" (Brundtland, 1987). According to the Report, this definition not only gives effect to the notion that priority must be given to the needs of the poor, but it also captures the limitations to development imposed by the present state of technology and social organisation on the environment's ability to meet present and future needs (Feris, 2010).

The definition therefore suggests an inherent link between social and environmental needs and the necessity for technological advancement and development. An imbalance among these elements, where global patterns of development put the environment under pressure, places the earth in crisis (Carley and Christie, 2000). This principle of integration between the three pillars of environment protection, economic development and social needs, is now widely recognised as a core element of sustainable development (Sands and Peel, 2012).

This principle was also recognised in BP Southern Africa (Pty) Ltd v MEC for Agriculture, Conservation, Environment and Land Affairs 2004 (5) SA 124 (W). The applicant sought the review and setting aside of a decision by the Gauteng Provincial Department of Agriculture, Conservation, Environment and Land Affairs (GDACE) to refuse the applicant's application in terms of section 22(1) of the Environment Conservation Act (ECA) 73 of 1989 for authorisation to develop a filling station on one of its properties. The Department based its refusal, inter alia, on environmental concerns. The applicant contended, however, that its application was refused not because the new filling station itself posed a danger to the environment, but rather because there were already two other filling stations within three kilometers of the applicant's site, and the Department regarded it as unacceptable to allow the proliferation of filling stations where existing filling stations were economically vulnerable to more competition. It argued that under the guise of 'environmental concerns', the Department was seeking to regulate the economy on the basis of what were essentially economic considerations unrelated to the environment.

The court explored the concept of sustainable development and in so doing, considered the wide definition of 'environment' employed by ECA which defines it in section 1 as: 'the aggregate of surrounding objects, conditions and influences that influence the life and habits of man or any other organism or collection of organisms'. According to the court, the broad definition of 'environment' would include all conditions and influences affecting the life and habits of man, 
which would also include socio-economic conditions and influences. With regard to the State's obligation under section 24(b), the court held that the Department was obliged to develop an integrated environmental management programme, which took cognisance of a wide spectrum of considerations, including international conventions and approaches as a result of the broad and extensive definition of 'environment' in ECA, which, inter alia, includes the consideration of socioeconomic conditions.

The socio-economic considerations of sustainable development received more detailed and eloquent attention in a relatively recent Constitutional Court judgment. In Fuel Retailers Association of Southern Africa v Director General Environmental Management, Department of Agriculture, Conservation and Environment, Mpumalanga Province 2007 (6) SA 4 (CC), the decision of the authorities to grant an environmental authorisation for the construction of a proposed filling station was challenged. The applicant specifically contended that the provincial authorities failed to consider the socioeconomic impact of the proposed development. As in the case of BP Southern Africa (Pty) Ltd v MEC for Agriculture, Conservation, Environment and Land Affairs 2004 (5) SA 124 (W), the Court stressed the inter-connected nature of environmental, social and economic considerations within the context of sustainable development and stated that:

\begin{abstract}
"The Constitution recognises the interrelationship between the environment and development; indeed it recognises the need for the protection of the environment whilst at the same time it recognises the need for social and economic development. It envisages that environmental considerations will be balanced with socio-economic considerations through the ideal sustainable development".
\end{abstract}

The concept of sustainable development places the duty to balance potentially conflicting principles on 'those who enforce and implement the Constitution' on the basis of proportionality (Kotzé, 2007). At the same time, the principle of sustainable development may actually serve the purpose of facilitating 'the achievement of the balance'. While the Court clarified that sustainable development required integrating the often contesting demand of economic development, social development and environmental protection, the question remains: how do we interpret sustainable development in a country which faces large scale poverty and where such a clear and unequivocal need for economic and social development is present?

The definition set out by the Brundtland Report captures the need for equity within generations as well as between generations. The principle of intra- generational equity (equity within generations) is essentially an approach that takes cognisance of the distributional demands of social justice (Feris, 2010). This is premised on the belief that distributional inequalities are causally responsible for a great deal of environmental degradation. Reducing inequalities can therefore be held to be a necessary means of achieving sustainability. This is of particular importance in the South African context, given the enduring nature of socio-economic inequalities in the country (Roberts, 2006).

In Minister of Public Works v Kyalami Ridge Environmental Association 2001 (3) SA 1151 (CC), the Court had an opportunity to assess and delineate the concept of sustainable development within the particular context of the South African economical landscape. In this particular case, heavy rains had led to extensive flooding and the subsequent destruction of the homes of approximately 300 people. The homeless flood victims were forced to live in tents erected on some municipal land, in overcrowded and unhealthy conditions without sufficient water and sanitation. It was decided to establish a transit camp on State land (at Leeuwkop Prison) as an emergency measure to provide temporary accommodation for flood victims until suitable, permanent housing could be provided.

The residents of land adjoining the proposed site for the transit camp (the Kyalami residents) brought an urgent application to the High Court for an interdict restraining the respondents from proceeding with the establishment of an informal settlement. The Kyalami residents argued that the government action was in contravention of the relevant town planning scheme as well as the applicable environmental legislation. They based their contention on the damage that would be done to the environment if a transit camp were to be established at Leeuwkop, and in doing so relied, among others, on their rights under section 24. The High Court granted an interim interdict and ordered the Government to comply with the necessary environmental legislation.

The Government appealed to the Constitutional Court, arguing that the appeal raised important constitutional considerations. One of the flood victims also intervened in the application, contending that the flood victims had a constitutional right to adequate housing.

While at first glance the case seems to raise competing interests, which are the right of access to adequate housing versus the environmental right, it was actually an opportunity to assess the State's duty in the context of its section 24(b) obligations and in particular, its duties in relation to sustainable development. As mentioned above, section 24(b) mandates the State to apply measures which will prevent pollution and ecological degradation, promote conservation, secure ecologically-sustainable development and the use of natural resources, while promoting justifiable 
economic and social development (Ferreira, 1999). The Kyalami residents' contentions essentially rested on the argument that the State negated this obligation by not providing for integrated environmental management of the site, including conducting an environmental impact assessment as required by environmental legislation. It was, however, never argued as such, or the Court simply did not consider sustainable development in this manner.

In essence, when fulfilling its mandate as set out in section 24(b), the State will have to make sure that it does so in a way which balances not only environmental considerations, but also social and economic considerations, in other words, sustainable development. In this regard, the South African reality is that the health and well-being of the lowerincome strata of the population are at a bigger risk than those of the middle-income and wealthy sectors (HST, 9952007).

The environmental concerns of the affluent sectors largely rest on the quality of life and well-being, which is threatened by atmospheric pollution, noise, congested transport, and the like (Feris, 2010). The environmental concerns of the poor- water pollution, lack of sanitation, overcrowding, distance from places of work, and the like-can have a much greater effect and may threaten their health and livelihood (Bartlett, 2008). The poor often suffer the double binds of the lack of access to basic services such as clean water, housing and health care, and a disproportionate share of the burden of environmental degradation (Feris, 2008).

A case can be made that distributional inequalities in economic and social welfare are causally responsible for a great deal of environmental degradation (Scruggs, 1998). There is therefore a nexus between poverty, underdevelopment and the degradation of the environment (Scherr, and Yadav, 1996). It is the poor who are most vulnerable to environmental degradation. Reducing economic inequalities and addressing social welfare concerns are often held to be necessary means of achieving sustainability (Elliott, 2012). But when is it appropriate to do so at the expense of environmental concerns? The Kyalami Ridge case missed an opportunity to assess sustainable development against the background of the competing interests inherent in the concept itself.

\section{The Relationship between Section 24 and Other Human Rights}

The nature of human rights is such that they do not operate in isolation, but may at times give rise to competing values (Okereke, 2006). In such situations, there is a need for guidance from the Court to indicate how the challenge of competing rights and gaining an understanding of the right to a healthy environment vis-à-vis other rights such as property rights may be met (Westra, 2008). Competing rights are not foreign to constitutional rights litigation (Alexy, 2010). Section 36(2) of the South African Constitution clearly states that rights can be justifiably limited in terms of 'any other provision of the Constitution.

Rights may therefore have a limiting effect on each other and may be used justifiably to infringe another right (Phillipson, 1999). This raises the question, however: what is the extent of the environmental right? In what instances can it operate to limit another right and vice versa? This issue was addressed in In Re Kranspoort Community 2000 (2) SA 124 (LCC).

The case concerned a claim for restitution of rights in land, in terms of the Restitution of Land Rights Act 22 of 1994, by the Kranspoort Community. The claim was disputed by the owner of the land and some of the objections raised were based on environmental concerns. It was argued that the area was environmentally sensitive and that the use at that time promoted the protection of the environment. Restoration would serve only to prejudice the sustainable management of the farm from an environmental perspective. The case pitted environmental considerations against section 35 property rights and more specifically rights stemming from restoration. The Court is given a wide discretion to grant relief in respect of a valid land claim by virtue of Section 35 of the Restitution of Land Rights Acts. In granting relief the court can consider a number of factors, including the feasibility of such restoration. Although the concept of feasibility is not defined in the Restitution of Land Rights Act, the test to be applied according to the Court is whether the restoration to the claimant of the right in land in question will be possible and practical, with regard to: (a) the nature of the land and the surrounding environment at the time of dispossession; (b) the nature of the claimant's use at the time of the dispossession; (c) the changes which have taken place on the land itself and in the surrounding area since the dispossession; (d) any physical or inherent defects in the land; (e) official land use planning measures relating to the area; and $(f)$ the general nature of the claimant's intended use of the land concerned.

In considering the first aspect of the test, the Court accepted that the area was environmentally sensitive and that the use at that time tended to promote the protection of the environment. It held, however, that if restoration would not prejudice the sustainable management of the farm from an environmental perspective, there should be no reason why the use of the land should hold sway over restoration. The Court, furthermore, held that the modern approach to conservation was not to consider protection of the environment as something which must necessarily exclude communities and their 
activities.

It focuses rather on co-opting communities into the sustainable management of the environment, especially considering that the community was part of the historical heritage of that specific area. The Court came to this position without explicitly taking section 24 into consideration. This is a pity, given that this type of sound reasoning and an attempt to harmonise competing rights would do much to augment the jurisprudence of section 24 . The Court did, however, consider section 24 in expending its powers under section 35(2)(c) of the Restitution of Land Rights Act, in prescribing how the restored rights in land were to be held and in imposing such conditions as is considered necessary to ensure that there was equitable access to the restored asset. In this respect it took into account sustainable development considerations. With reference to the risk of unsustainable depletion of renewable resources on the farm, it referred to the need to consider the ability of younger members of the community to have equitable access to the restored asset in the future.

It therefore considered the need of future generations (without expressly referring to it), which relates to intergenerational equity, which can arguably be considered one of the primary components of sustainable development. The Court believed that conditions aimed at eliminating the risk of such depletion were in line with section 24(b) of the Constitution.

In contrast to the notion of competing values, human rights are also understood to be mutually reinforcing (Nixon and Forman, 2008). The principle of 'interdependency' has therefore been recognised and endorsed in various human rights instruments (the Vienna Declaration and Programme of Action, adopted by the World Conference on Human Rights, June 1993, UN Doc A/Conf 157/23, Part I, para 5). This discourse has found a particular place in the realm of second-generation rights and is similarly sound when one talks about third-generation rights, such as the environmental right. This principle of interdependence is understood to operate within a dual context. First, in the organic sense, one right forms a part of another right and might therefore be incorporated into that latter right. Thus one (core) right justifies the other (derivative) right (Donnelly, 2013).

An opportune moment arose to assess the relationship between property rights, freedom of expression and the environmental right. In Petro Props (Pty) Ltd v Barlow 2006 (5) SA 160 (W), Barlow, together with an environmental association dedicated to the preservation of a wetland area, publicly opposed the development of a fuel service station in a wetlands area. The respondent opposed the development primarily because it was taking place in an ecologically sensitive area. The applicant was the owner of an immovable property on which, having obtained all the necessary consents, it was constructing a fuel service station and a convenience store. The project was backed by a major national petrochemical concern, Sasol (Pty) Ltd (Sasol), and the viability of the project depended on Sasol's backing. Barlow's opposition took the form of an ongoing public campaign against the development, a campaign that had been 'successful' to the extent that it had brought Sasol to the brink of withdrawing its backing of the project.

The applicant therefore sought to interdict the respondent from continuing her campaign to prevent it from exercising its rights in respect of its property, in particular its right to construct a service station and convenience store. The applicant's primary argument was that it had a right to construct a petrol station on its own property and that throughout the campaign, it had been persistently and unlawfully harassed by the respondent. It contended that its fundamental right to property under section 25 of the Constitution had to prevail over the respondents' fundamental right to freedom of expression under section 16 of the Constitution.

Barlow contended that a company and its associates had a constitutional right under section 16 to conduct the campaign and to question the process whereby the applicant had secured the necessary consent. She furthermore also relied on section 24, to which the applicant responded that the terms of that environment right meant that it was the State alone which had to give effect to it, and that it therefore operated against the respondents, whose active pursuit of a campaign such as this one was thereby excluded.

While the Court upheld Barlow's defense, it chose not to consider any of the arguments raised vis-à-vis section 24. The Court's reasoning focused on the opposing claims raised in terms of the rights to property and the right to freedom of expression, relegating section 24 to a footnote which noted that 'in the context of this case, the environment right in section 24 is subsumed under a debate on freedom of expression'.

This scant reference to section 24 is wholly insufficient. After all, Barlow and the Libradene Wetland Association's expression of dissatisfaction with the actions of the applicant were motivated first and foremost by environmental considerations, their concerns about the threat of degradation to an ecologically sensitive wetland. The context for their protest was more appropriately articulated, therefore, in section 24 and their right to an environment that was free from degradation. The Court acknowledged the environmental interest which drove the expression of the respondents in its application of a two-stage analysis in which the first step assessed the degree to which the constitutional protection of 
expression extended to the protection of the respondents' campaign.

It noted the 'selfless' interest and motivation of the respondents, aimed at contributing to environmental protection for the common good. It failed, however, to relate this motivation to the environmental right. On the face of it, the relationship between freedom of expression and environmental rights seemed tenuous. This relationship has to be reviewed, however, in the context of the growing tendency in South Africa to file defamation lawsuits against citizens and public interests groups that publicly object to conducts that threatens the environment.

\section{Conclusion}

It is beyond doubt that the current trends all over the world is to ensure that various steps are taken to ensure clean environment. While enforcement and implementation of environmental laws and policies will help in bringing polluters to book, it is equally important that preventing pollution should be taken seriously. Against the backdrop of this, before any project commences, a clear assessment of its environmental impacts should be carried out and if found that it will pollute the environment, immediate measures to address this should be carried out. This is being environmentally proactive. However, with regard to the existing projects or activities, monitoring and evaluation are required in order to make sure that their activities are being carried out within the purview and limits of the law.

\section{References}

Albertyn C, Goldblatt B 1998. Facing the Challenge of Transformation: Difficulties in the Development of an Indigenous Jurisprudence of Equality, South African Journal on Human Rights, 14:248-249.

Ackerman F, Heinzerling L 2001. Pricing the priceless: Cost-benefit analysis of environmental protection.From http://scholar.google.com/scholar?q=\&btnG=\&hl=en\&as_sdt=0\%2C5. (Retrieved January 6, 2012).

Alexy A 2010. A theory of constitutional rights, Oxford University Press, Oxford, UK.

Anand S 2000. Human Development and Economic Sustainability, World Development, 28(12):2029-2049.

Bartlett 2008. Climate change and urban children: impacts and implications for adaptation in low- and middle-income countries, Environment and Urbanization, 20(2): 501-519.

Bartelmus P 2002. Environment, growth and development: the concepts and strategies of sustainability, Routledge, London, UK.

Brundtland GH 1987. World commission on environment and development- Our common future, From http://scholar.google.com/scholar?q=World+Commission+on+Environment+and+Development+\&btnG=\&hl=en\&as_sdt=0\%2C5. (Retrieved December 4, 2012).

Carley MJ, Christie I 2000. Managing sustainable development, Earthscan Publication Ltd, UK.

Chipkin I, Meny-Gibert S 2013. Understanding the Social Justice Sector in South Africa. From raith.org.za. (Retrieved Octobr 29, 2013).

Crane A, Matten D 2007. Business ethics: Managing corporate citizenship and sustainability in the age of globalization, Oxford University Press, UK.

David A, Pape J 2002. Cost Recovery and the Crisis of Service Delivery in South Africa. From http://www/hsrcpress.ac.za. (Retrieved May 19, 2012).

Davis DM 2008. Socioeconomic rights: Do they deliver the goods? International journal of constitutional law, 2008. 6:(3-4):687-711.

Donnelly J 2013. Universal human rights in theory and practice, Cornell University Press, USA.

Dudley N 2008. Guidelines for applying protected area management categories, IUCN Publications, Norwich, UK.

Eastwood J 2007. Managing the relationship between the national government and the provinces. A discussion of provincial environmental initiatives with reference to section 24 From publiclaw.uct.ac.za. (Retrieved September 9, 2013).

Elliott J 2012. An introduction to sustainable development, Rutledge, New York, USA.

Farmer A 2007. Handbook of environmental protection and enforcement: Principles and practice, Earthscan Publishers, UK.

Feris L 2008. Constitutional Environmental Rights: An Under-utilised Resource. From http://heinonlinebackup.com/hol-cgibin/get_pdf.cgi?handle=hein.journals/soafjhr24\&section=5. (Retrieved June 4, 2012).

Feris LA 2010. The role of good environmental governance in the sustainable development of South Africa, Potchefstroom Electronic Law Journal, 13(1):1-28.

Ferreira GM 1999. Volhoubare Ontwikkeling, Regverdige Ontwikkeling en die Fundamentele Reg op 'n Skoon en Gesonde Omgewing, South African Law Journal, 3:436-437.

Goodland R 1995. The concept of environmental sustainability, Annual Review of Ecology and Systematics, 26:1-12.

Henrard K 2002. Post apartheid South Africa's democratic transformation process: Redress of the past, reconciliation and 'unity in diversity, Global Review of Ethnopolitics, 1(3):18-38.

HST, 1995-2007. Health Systems Trust. The South African Health Review (1995-2007), From http://www.hst.org.za/generic/29. (Retrieved July 19, 2013).

Hunter D, Salzman J 2007. Negligence in the Air: The Duty of Care in Climate Change Litigation, University of Pennsylvania Law Review, 155(6):1741-1754.

Kotzé LJ 2007. The Judiciary, the Environmental Right and the Quest for Sustainability in South Africa: A Critical Reflection, Review of 
European Community \& International Environmental Law, 16(3):298-311.

Le Roux N 2012. Environmental governance, fragmentation and sustainability in the mining industry. From http://dspace.nwu.ac.za /handle/10394/7398. (Retrieved April 11, 2013).

McDonald DA 2004. Environmental Justice in South Africa, Ohio University Press, Ohio, USA.

Madalane T 2012. The obligation to rehabilitate mining areas: post mining activities. From http://ul.netd.ac.za/handle/10386/905. (Retrieved July 19, 2012).

Mazmanian D, Kraft ME 2008. The three epochs of the environmental movement. From http://papers.ssrn.com/sol3/papers.cfm ?abstract_id=1516819. (Retrieved May, 4, 2012).

Nevondwe LT, Mhlaba MW 2012. Judicial Activism and Socio-Economic Rights in South Africa, Limpopo, South Africa.

Naughton-Treves L, Holland MB 2005. The role of protected areas in conserving biodiversity and sustaining local livelihoods, Annual Review of Environment and Resources, 30: 219-252.

Nixon S, Forman $L$ 2008. Exploring synergies between human rights and public health ethics: A whole greater than the sum of its parts. From http://www.biomedcentral.com/1472-698X/8/2. (Retrieved September 4, 2013).

Okereke C 2006. Global environmental sustainability: Intragenerational equity and conceptions of justice in multilateral environmental regimes, Geoforum, 37(5):725-738.

Phillipson G 1999. The Human Rights Act, Horizontal Effect and the Common Law: a Bang or a Whimper? The Modern Law Review, 62(6):824-849.

Razzaque J 2002. Human rights and the environment: the national experience in South Asia and Africa. From http://www2.ohchr.org lenglish/issues/environment/environ/bp4.htm. (Retrieved February 4, 2013).

Roberts B 2006. The happy transition? Attitudes to poverty and inequality after a decade of democracy, HRSC Press, Cape Town, South Africa.

Samuelson PA 2012. Economics of Forestry in an Evolving Society, Journal of Natural Resources Policy Research, 4(3):173-195.

Scruggs L A 1998. Political and economic inequality and the environment, Ecological Economics, 26(3):259-275.

Scherr SJ, Yadav S 1996. Land degradation in the developing world: Implications for food, agriculture, and the environment to 2020. From pdf.usaid.gov (Retrieved March 9, 2012).

Scott C 1989. The Interdependence and Permeability of Human Right Norms: Towards a Partial Fusion of the International Covenants on Human Rights, Osgoode Hall Law Journal, 27:779-783.

Sands P, Peel J 2012. Principles of international environmental law, Cambridge University Press, Cambridge, UK.

Scott C, Macklem P 1992. Constitutional Ropes of Sand or Justiciable Guarantees? Social Rights in a New South African Constitution, University of Pennsylvania Law Review 141(1): 1-148.

Therivel R 2012. Strategic environmental assessment in action, Earthscan, London, UK.

Van der Linde M 2006. Compendium of South African Environmental Legislation, Pretoria University Law Press, Pretoria, South Africa.

Waite A 2005. The quest for environmental law equilibrium, Environmental Law Review, 7(1):34-62.

Westra L 2008. Environmental Justice and the Rights of Unborn and Future Generations: Law, Environmental Harm and the Right to Health, Earthscan, London, UK. 